\title{
FACSIMILE PLATES
}

FACsimile 1. Folio $8^{\mathrm{v}}$ of the Black Pocket-book, sketches from 190842

FAcsimile 2. Folio 9r of the Black Pocket-book, sketches from 190843

FACsimile 3. Folio 11' of the Black Pocket-book, sketches from 190845

FACsImile 4. Sketches for The Wooden Prince 46

FACsimile 5. Sketch page from 1926 with unused thematic ideas probably for Piano Concerto no. 1 and the themes of the finale of the Piano Sonata 49

FACsimile 6. Sketch from 1926, the first notation of the "Ostinato" (Mikrokosmos no. 146) 51

Facsimile 7. Sketches from 1926, unused ideas for Piano Concerto no. 1 and the beginning of Movement III $\quad 52$

FACsIMILE 8. Bartók's handwriting with six birdsongs; no. 6 used in Movement II of Piano Concerto no. $3 \quad 55$

FACsImILE 9. Sketches from 1939 for Movements III, I, and II of the Divertimento 59

FACsimile 10. First page of the draft of the Violin Concerto (no. 2), 1937 62

Facsimile 11. First page of Movement I of the draft of Piano Concerto no. 3, 194565

Facsimile 12. Sketches for Movement II in the draft score of Piano Concerto no. 2, on the page with the end of Movement I, 1930 or $1931 \quad 67$

FACsimile 13. Folio $27^{\vee}$ of the Black Pocket-book with sketches for the Sonata for Violin and Piano no. 2, $1922 \quad 72$ 
FACSIMILE 14. Folio 28 of the Black Pocket-book with the continuation of the sketches for the Violin Sonata no. $2 \quad 73$

FACsimile 15. Draft with sketches of Movement II of the Sonata for Solo Violin in the Arab field-book, $1944 \quad 78$

Facsimile 16. Partial sketches to the score of the Dance Suite, 192379

FACsimile 17. One-page fragment of a piano piece, ca. $1918 \quad 88$

FaCsimile 18. Fragment of a piano piece, among the sketches for the Piano Concerto no. 190

FACsimile 19. Fragment in the Turkish field-book, 1943, among the sketches and the draft of the Concerto for Orchestra $\quad 92$

FACSIMILE 20. Orchestral fragment ca. 1943 (?), planned as an episode for the orchestrated version of the chorus "Hussar" 93

FACsimile 21. Fragment perhaps for String Quartet no. 7 (?) in the Arab field-book, 1944 or $1945 \quad 94$

FACSIMILE 22. Corrections and sketches for the beginning of Movement I in the draft of String Quartet no. 6, $1939 \quad 108$

Facsimile 23. The Wooden Prince, p. 31 of the draft, ca. 1916123

Facsimile 24. Four Orchestral Pieces, the last page of Movement IV in the draft, ca. $1912 \quad 124$

Facsimile 25. Violin Concerto (no. 2), p. 4 of the draft, $1937 \quad 125$

Facsimile 26. Viola Concerto, p. 1 of the draft, $1945 \quad 126$

Facsimile 27. Piano Concerto no. 3, p. 7 of the draft 127

Facsimile 28. Piano Concerto no. 2, p. 11 of the draft score 128

FACsimile 29. Music for Strings, Percussion, and Celesta, p. 40 of the draft score, 1936129

FaCsimile 30. Piano Sonata 1926, the beginning of Movement I in the draft 130

Facsimile 31. Piano Sonata 1926, the beginning of Movement $I$ in the first autograph copy 131

FAcsimile 32. The draft of "Bagpipe" (Mikrokosmos no. 138), ca. 1937132

FACsimile 33. String Quartet no. 6, the first page of the draft 133

FACsimile 34. Draft of "Wandering," from Twenty-Seven Choruses, 1935 or 1936 and a sketch for Mikrokosmos no. $98 \quad 134$

FACSIMILE 35. String Quartet no. 5, the beginning of Movement II in the draft 135

FACsimile 36. String Quartet no. 1, p. 3 (Movement I) of the draft, 1908-1909 136 
FACsimile 37. Sonata for two Pianos and Percussion, sketchy page of the draft, $1937 \quad 137$

Facsimile 38. Sonata for two Pianos and Percussion, p. 35 of the draft 138

FACSIMILE 39. Contrasts, for violin, clarinet, and piano, the end of Movement III in the draft, with a side sketch for Movement II, $1938 \quad 139$

FACsimile 40. Suite op. 14, for piano, the discarded original Movement II in the draft, 1916140

Facsimile 41. String Quartet no. 5, the beginning of the first version of Movement III in the draft, $1934 \quad 141$

Facsimile 42. Piano Concerto no. l, p. 1 of the original full score 208

Facsimile 43. Piano Concerto no. 1, p. 1 of the autograph copy of the full score 209

FACSIMILE 44. Bartók's copyists. Samples of handwriting by family members 210

FACsimile 45. Bartók's copyists. Samples of handwriting by copyists Anon. Y and Anon. X, Jenó Deutsch, Erwin Stein, and Tibor Serly 211

FACsimile 46. Violin Concerto op. posth., the solo violin part written by Anon. Y 212

Facsimile 47. Sonata for Violin and Piano no. 1, Márta's copy of the violin part, 1921, with Bartók's additions and corrections 212

Facsimile 48. Piano Concerto no. 2, handmade 2-piano reduction based on the Lichtpausen, ca. $1932 \quad 217$

FACsimile 49. The Miraculous Mandarin, p. 9 of the draft 222

FACsimile 50. The Miraculous Mandarin, p. 22 of the autograph copy of the piano 4-hand reduction 223

FACsimile 51. Violin Concerto (no. 2), Movement I, p. 11 of Bartók's violin-and-pianoform working copy 224

FACsimile 52. Violin Concerto (no. 2), Movement III, p. 31 of the draft 225

FACsimile 53. J.S. Bach's Sonata VI (BWV 530), autograph of Bartók's transcription 234

FACsimile 54. Seven Sketches, first page of the corrected proof sheets of the Rozsnyai edition 241

FACsimile 55. String Quartet no. 1, excerpt from Movement I in the Rózsavölgyi pocket score edition and in the draft 242

FACsimile 56. Violin Concerto (no. 2), p. 51 of the corrected proof sheets of the Boosey \& Hawkes full score 244

FACsimile 57. String Quartet no. 4, the beginning of Movement III in the sketchy draft, full draft, and autograph copy 271 
